\title{
PEDAGOGY
}

\section{THE PHENOMENON OF "ACMEOLOGICAL CULTURE” AND APPLICATION OF ACMEOLOGICAL APPROACH IN PROFESSIONAL TRAINING}

\author{
Olha Ocheretna, Ph.D. in Pedagogical Sciences, Docent, National University «Odessa Maritime \\ Academy»; Department of English №2, Odessa, Ukraine; \\ Maiya Goncharenko, Senior teacher of English, National University "Odessa Maritime Academy», \\ Department of English №2, Odessa, Ukraine
}

DOI: https://doi.org/10.31435/rsglobal_wos/30042020/7046

\section{ARTICLE INFO}

Received: 17 February 2020

Accepted: 11 April 2020

Published: 30 April 2020

\section{KEYWORDS}

acmeological approach, professional training, professional training, acmeological culture. \begin{abstract}
Digressing from the problem, which is considered in this research, and its solution within acmeological approach, the aim of the study is to find its origins and determination of its role in the development of professional competence of future specialists during their studies in higher education institutions.

Synthesizing knowledge of many sciences and applying main elements of modern approaches, the notion of "acmeological culture" presents more specific interpretation of the development of professionalism and professional competence.
\end{abstract}

Citation: Olha Ocheretna, Maiya Goncharenko. (2020) The Phenomenon of “Acmeological Culture" and Application of Acmeological Approach in Professional Training. International Academy Journal Web of Scholar. 4(46). doi: 10.31435/rsglobal_wos/30042020/7046

Copyright: (C) 2020 Olha Ocheretna, Maiya Goncharenko. This is an open-access article distributed under the terms of the Creative Commons Attribution License (CC BY). The use, distribution or reproduction in other forums is permitted, provided the original author(s) or licensor are credited and that the original publication in this journal is cited, in accordance with accepted academic practice. No use, distribution or reproduction is permitted which does not comply with these terms.

Introduction. One of the most important priorities among social priorities of our society is constant improvement of professional training of the students, which tend to achieve dominance through forecast, design, modeling, planning of future and determination of their roles in this process. Continuing positive heritage of the traditional system of higher professional education for students of technical education institutions, modern approaches to it allow to create conditions, which conform future professional knowledge to modern scientific views and theories. Within this context a future professional is provided the right to choose the way, which allows to achieve greater levels of professionalism. For modern pedagogical science expansion of the terminological device the concept of the acmeological approach takes the steady place when its methodological importance is defined by its essence. In pedagogical science the philosophical understanding of acmeology as a science studying laws and mechanisms of development of the person during its maturity, is transformed because of its orientation on the research of the laws causing the person achieving the tops of professionalism in activity. The important task of acmeology in this sense is finding-out what it should be generated in the person in his childhood and youth he could realize his potential successfully at the period of his maturity. Acmeology is a new direction of interdisciplinary researches of the person. The necessity of its origin is explained basically by the sociocultural context of development of a transitive society which is compelled to solve the problems of the global-crisis character. Actually one of the major human resources of the optimum solution of these problems are high professionalism and creative skill of experts. As acmeology studies laws and technologies of professionalism development and creativity as acme-forms of every possible kinds, optimum realization of professional activity it 
means that the integral-complex science gets special value for theoretical development and removals of social intensity in the sphere of human mutual relations.

Purpose of the study: to determine and to find the origins of acmeological approach in professional training.

The questions of professional competence of the expert draw attention of many modern scientists which recently displace accent on social values of personal qualities of the expert. Thus today there were certain directions in pedagogical development. The first direction is connected with the phenomenon "culture" which is a result of development of the person, his erudition and good manners.

The common cultural competence is presented as a set of three aspects:

- semantic, which includes the adequacy of judgement of understanding the situation in a cultural context, that is in the context of available cultural samples of understanding, attitude, estimation;

- problem-practical, providing the adequacy of recognition of the situation, adequate definition and the effective performance of the purposes, problems, norms in given conditions;

- communicative, focusing attention to the adequate dialogue in situations of a cultural context and as to such situations taking into account the corresponding cultural samples of communication and interaction.

In this case the professional competence is a derivative component of any person's common cultural competence. Thus, V. Vakulenko, is guided by the notion «pedagogical culture» to satisfy the definition of pedagogical competence, as dynamic system of pedagogical values, ways of activity and professional work of the teacher [1].

The second direction unites pedagogical research of professional competence where this concept is considered as a system of qualities, skills. V. Maksimova represents professional competence as the system including aspects of philosophical, psychological, sociological, cultural and personal order [2].

«Professional competence of people working in the system «individual - individual» (teachers, doctors, lawyers, maintenance staff), is defined not only by fundamental knowledge and skills but also by valuable orientation of the expert, motives of his activity, self-understanding in the environment, style of relationship with people he works with, his culture, ability to develop his creative potential.

In a profession of the teacher the knowledge methods of a subject teaching; ability to understand and influence an inner world of the pupils; respect for them is added to this list. The absence of even one of the components destroys the whole system and reduces the efficiency of the teacher's activity». Hence, such parameters of the investigated concept, as possession of a professional knowledge and skills, valuable orientations in society, the culture shown in speech, style of dialogue, the attitude of the teacher, the practical activities and its realization are noted.

V. Gladkova understands as professional competence «the system of knowledge, skills and abilities, professionally significant qualities of the person providing an opportunity to fulfil the professional duties of a certain level» [3].

The third direction is connected with the professional training of the future specialists.

O. Ganzha includes in the content of professional training invariant and variant parts forming some set, possessing elements of integrity. An invariant (obligatory) part consists of: fundamental knowledge in the field of philosophical, psycological-pedagogical and methodical sciences; technological knowledge in the field of the organization of various forms and kinds of educational and out-of-class activity; professional-pedagogical skills. Variant part considers the pecularities of a structure of scientific preparation of the student, his personal interests and propensities [4]

L. Rybalko treats professional competence as the form of realization of the pedagogical activity, caused by «the profound knowledge of properties of transforming subjects (the person, group, collective) of this activity, easy control of instruments of production, conformity of the concrete subject content of work, character of carried out works to subjective, professionally important qualities of the teacher, its self-estimation, industry». Differently, representatives of the given direction consider, that competence and skill are close concepts [5].

The fourth direction of professional researches competence is connected with an establishment of concepts parity «professional competence» and «readiness for professional work». In the theory of professional training the last has received wide enough development, that's why the wide enough range of associative raw becomes clear when it is treated as: directive; a prestarting condition, (X. Shaparenko); the active condition of the person causing activity; a condition of vigilance; set of 
professionally caused requirements to the teacher; the complex structural formation including professionally significant qualities of the person, motives, needs, interests, skills and abilities; an essential component of professional competence; result of professional training .

$\mathrm{X}$. Shaparenko understands professional competence of a teacher as «the unity of its theoretical readiness to think pedagogically and practical readiness to operate pedagogically». He considers professional competence of the person «as the individually-integrated qualitative characteristic of the subject of activity, a complete condition and readiness of the person for its realization».

Readiness for pedagogical activity, in Shaparenko's opinion, is «a compound component of professional competence and represents reflexed orientation of the teacher on a pedagogical profession, a world outlook maturity; aim at constant professional and personal perfection, selfrealization and self-education; aim at forecasting and dynamism in designing author's technology of children training and education» [6].

The fifth direction considers professional competence from the psychological point of view as the characteristic of the person and brings into its content productive component. As a whole, competence is a parameter of «the formation of the necessary skills and abilities, a level of their possession». G. Kovalenko considers professional competence «as the most important characteristic of the teacher's preparation, set of communicative, constructive, organizing skills, and also ability and readiness to use these skills practically in the work» [7].

The following direction of scientific and pedagogical researches of professional competence problematics treats it as qualities of the person which are necessary not only for direct participation in training and education of students, but also for the organization of own and student's activity.

The notion "acmeological culture" traces back to the development of complex approach in acmeology by B. Ananiev, in which the scientist emphasized its great opportunities in the orientation to the unity of studying and real practical improvement of a person through the transformation of the existing level of development into a higher, optimal one, uniting the detached aspects of person's functioning and his development on the life way and in different types of activity.

For the past few years the scientists has eveloped and applied the acmeological approach in the research of problems of different nature, where professional activity plays the main role. The notion "acmeological culture" in education sphere "acts as a new scientific-methodological trend, which concerns the development of models and projects of establishing of a person on the level of his highest achievements, improvement of a person as an individuum, personality, subject of activity, individuality. The acmeological approach forms part of methodological foundations of the researches of psychological and pedagogical nature in many scientific works. The acmeological culture of personal-professional development of a person is understood in the researches of the last decade as a willingness to innovations, planning of own activity goal, which is oriented to a high result, life successes, modeling of professional self-improvement's route taking into consideration one's own potential abilities and society demands. The establishment of the acmeological culture is classified by Derkach as "implementation of complex investigation and restoration of integrity of the subject, which undergoes the stage of maturity, when his individual, personal, subjective and activity characteristics are studied in unity, in all interconnections and mediations in order to assist in achievement of the higher levels, which can be reached by any person [8].

The goal of the acmeological culture's development within the achievement of the higher levels of professional competence is presented as solution of the range of problematic tasks during the process of reaching "acme". However, "acme" doesn't mean the final point of life movement to the development; it means the top, from which the new horizons of professional development are opened. Many works of scientists-acmeologists disclose the acmeological culture in the planning of advancement to the reaching professional top, tendency to high professionalism, which is represented by professional competency.

The same works prove that the system of improvement of vocational education in higher education institutions can be successfully realized on the basis of the development of the acmeological culture, where acmeological strategy of professional education is understood as projecting, planning and organization of a future specialist's professional achieving, maximum use of his personal and professional potential with the application of acmeological technologies (self-development, reflexive and others).

The researches of the scientists, who consider the acmeological culture as the establishment of the education system and self-formation of personality, are taken into consideration in this work 
(Derkach and others). The scientists consider that in the process of realization of comprehensive education an acmeological goal should be set forward, which consists of integral growing person's development, formation of humanistic life values, application of the acmeological influence methods (solution of the acmeological tasks, which oriented to the realization of creative potential in socially significant activity); usage of acmeological technologies in the achievement of success by every person, establishing the acmeological positions, tendency to acmeological maturity.

Potential of the acmeological culture formation is determined by the fact that the most important factor of a future specialist's personal reformation is active development of creative and intellectual potential of every person. The essence and inner structure of creativity interwine with the specialist's consciousness, his thinking, perception, foresight, ideals. The essential feature of creativity is its synthesizing, goal-oriented, prognostic tendency for higher levels of professionalism, which is expressed by professional competence. The scientists in the higher education industry proved that the application of the acmeological culture to the realization of the future specialist's professional training is not only necessary, but it is perspective and stimulates the route to success in professional activity, to the tops of individual creativity.

The complex structural essence of the acmeological culture as psychological and pedagogical studies point out provides the removal of contradictions between different points of view to the factors, which characterize effective professional students' training of higher vocational education due to the creation of special pedagogical (acmeological) environment for comfortable teaching and studying, creation of such continuous feeling of the participants, which stimulates their aspiration for self-actualization, creativity, success and reflection.

Under the assertion of some researchers in the development of acmeology it is possible to emphasize four basic stages and approaches in professional training:

- latent, when the historical, sociocultural, scientific-theoretical preconditions of distinguishing a new sphere of human science in scientific knowledge were developed;

- nominational, when the social need for such knowledge was realized and designated by N. Rybnikov's introduction in 1928 the special term "acmeology";

- incubatory, its beginning is dated the occurrence of conceptual idea of N. Kuzmina about the necessity of constallation the researches of acmeological problematics as a new area of human science. The precondition were systematization and generalization, the analysis and differentiation of human science of the second third of XX centuries in Derkach's works. This stage is finished with program promotion of the acmeology expansion as special discipline;

- institutional, this stage is connected with creation of some social structures: acmeological faculty, laboratories in high schools and, at last, the International academy of acmeological sciences. Within these scientifically-educational structures researches are investigated, acmeological technologies and vocational training are developed.

However, it is difficult to agree with those scientists who allocate the fifth stage of development of acmeology, connected with its philosophical substantiation. So, historiosophical approach of Edward allowed to watch the integral approach and interrelation of acmeology with cultural science, with philosophical anthropology, with ethnoacmeology, Baynham analysed the development of acme as the element of philosophical knowledge in history of philosophy, under the direction of O. Grechannik there was a school which investigated a fundamental problem - the development of person's abilities and their influence on productive activity in all spheres of life.

Research results. Five stages of acmeology development as a science allowed to draw a conclusion about a new quantum leap of acmeological knowledge. The stage of acmeological knowledge's practical application and acmeological method began.

Acmeology as any other area of scientific knowledge has not only general scientific principles, but also the concrete disciplinary features which characterize it as a specific branch of in detail-methodical knowledge. As it is formed scientific discipline the definition of its in detail-methodical specificity and categorical-methodological context represents a special task where the ways of decision depend on the further development of the concrete acmeological researches. There are three basic methodological orientations in them: natural-science, technological and humanitarian. For us, the last one, as belonging to the sciences of the human beings, acmeology finds the ontologic definiteness as the most important one on the basis of genetic interaction with these sciences during historical development and, on the other hand, in the subject isolation from them as formed independent discipline. 
Conclusions. As numerous acmeologic-pedagogical studies show, the projective and constructive capabilities for the achievement of professional "acme" through establishing professional competence occupy one of the first places together with gnostical, communicative, organizational and other capabilities of a future specialist in the realization of the acmeological approach.

Projective capabilities form special ability of the teachers and students to forecasting, development, modeling of own educational route, which should be used for the way from ignorance to knowledge, creation of creative atmosphere in the conditions of mutual activity of teacher with students, awareness of the progress on the way to new knowledge, growth and development.

Therefore, goal orientation to the development of creative individuality and provision of successes of every specialist, development of synergic ability of a personality to self-organization as self-preparation, self-education, self-instruction, self-actualization, self-expression and selfimprovement in creative activity, acquire important significance in the acmeological approach.

Grounding on the analysis of the researches works, we define the acmeological approach to the development of professional competence of future specialists as the methodological foundation of this research, whose main goal is self-prediction, modeling, self-projection in the achievement of professional "acme". Within the formation of the acmeological culture the logic of self-projection of professional way a personality from "awareness of imperfection" to establishing himself in an investigational searching position, value self-determination in the problematic field of selfprogramming, planning, reflection and achievement of higher level of professional "acme" become the foundation for the development of professional competence of a future specialist.

\section{REFERENCES}

1. Вакуленко В. М. Вступ до акмеології педагогічної освіти: монографія / В. М. Вакуленко. Алчевськ: ДГМІ, 2003. - 149 с.

2. Максимова В.Н. Акмеологическая теория в контексте проблемы качества образования / В. Н. Максимова // Педагогика. - 2002. - № 2. - С. 9-14.

3. Гладкова В. М. Професійний саморозвиток майбутнього фахівця сфери «Людина-Людина» / В.М. Гладкова // Оновлення змісту, форм та методів навчання і виховання в закладах освіти: зб. наук. праць Рівненського державного гуманітарного університету. - Вип. 13(56). - Ч. ІІ. - Рівне: РДГУ, 2016. - С. 5-7.

4. Ганжа О. В. Формування соціально-професійної зрілості майбутнього вчителя історії у навчальновиховному середовищі: дис... канд. пед. наук: 13.00.04 / О. В. Ганжа. - Кіровоград, 2011. - 258 с.

6. Рибалко Л. С. Методолого-теоретичні засади професійно-педагогічної самореалізації майбутнього вчителя (акмеологічний аспект): монографія / Л. С. Рибалко. - Запоріжжя: ЗДМУ, 2007. - 442 с

7. Шапаренко Х. А. Формування професійної компетентності майбутніх вихователів дошкільних навчальних закладів на засадах акмеологічного підходу: дис... канд. пед. наук: 13.00 .04 / X. А. Шапаренко. - Харків, 2008. - 236 с.

8. Коваленко Г. С. Формування акмеологічної позиції майбутнього вчителя в процесі фахової підготовки: дис... канд. пед. наук: 13.00.04 / Г. С. Коваленко. - Кривий Ріг, 2010. - 279 с.

9. Деркач А. А. Акмеологические основы развития профессионала / А. А. Деркач. - М.: МПСИ, 2004. - 752 с. 